is demonstrated by the fact that an African species of malaria-carrying mosquito, Anopheles gambice, has become established in South America. According to Science Service, this mosquito has been found at Natal, Brazil, and in localities two hundred miles west and north of Natal, and has already caused severe outbreaks of malaria. This mosquito was probably introduced as a stowaway on one of the aeroplanes of the French airline between Dakar in West Africa and Natal in Brazil.

\section{Cadmium Pigments}

WE have received from Messrs. Johnson and Matthey, Hatton Garden, London, E.C.1, a copy of a booklet on cadmium pigments. These have cadmium sulphide as a basis, and the sulphide itself can be obtained in any colour from pale yellow to orange. Redder shades are obtained by the incorporation of selenium, so that it is possible to get a complete range from pale yellow, through orange and red, to deep maroon. Cadmium lithopones are also available. The properties of the pigments are described.

\section{High Vacuum Distillation}

ThE Transactions of the Society of Chemical Industry (58, No. 2 ; 1939) contain several papers presented last November to a meeting of the Chemical Engineering Group which dealt with the industrial applications of high-vacuum distillation. Pressures of the order of $10^{-6} \mathrm{~mm}$. are concerned and the technical apparatus is described with drawings. One important application of the technique is to the concentration of vitamins from oils.

\section{Earthquake in Solomon Islands of April 30, 1939}

FURTher news has come to hand concerning this shock. According to the Bureau central seismologique de Strasbourg, from reports received from thirty seismological stations the epicentre of the most severe shock was at $7 \cdot 5^{\circ} \mathrm{S}$., $159 \cdot 6^{\circ} \mathrm{E}$., depth of focus probably $100 \mathrm{~km}$. and starting time $2 \mathrm{~h}$. $55 \mathrm{~m}$. $35 \mathrm{~s}$. G.C.T. According to reports from the islands, the shock and after-shocks lasted for several days. One of the islands most seriously affected was Guadalcanar, where a number of buildings were wrecked, and where a wave following the shock swamped a number of native villages. On Ysabel Island houses were damaged, and in the Cape Marsh district of the Russell Islands wharves and houses were wrecked. In the island of Savo, surface faults were visible, but there was no loss of life. Altogether nine children and three adults of the indigenous population were drowned.

\section{Earthquake near Japan}

UsING reports from the seismological stations at Honolulu, Victoria, Tucson, Manila, Huancayo, Zikawei, Burlington and Philadelphia, the United States Coast and Geodetic Survey has made a preliminary determination of the epicentre and initial time as follows : lat. $37^{\circ} \mathrm{N}$., long. $142^{\circ} \mathrm{E}$., November 30,2 h. 29 m. 52 s. G.C.T. The epicentre is under the ocean bed to the north-east of the coast of the main island of Japan, and is the same as that for the earthquake of November 22, lh. 14.1m. G.C.T. No effects of this shock have been reported from land.

\section{Commonwealth Fund Fellowships Awards}

THE Committee of Award of the Commonwealth Fund fellowships has made the following appointments, among others, to fellowships tenable by British graduates in American universities for the two years beginning September 1939: C. A. U. Craven, Imperial College of Science and Technology, University of London, to Harvard University, in geology ; Dr. B. M. Crowther, Clare College, Cambridge, to the Massachusetts Institute of Technology, in physics; G. M. Henderson, University of Edinburgh, to Princeton University, in chemistry; P. B. Hunt, Christ Church, Oxford, to Columbia University, in economics ; G. O. Jones, Emmanuel College, Cambridge, to the Massachusetts Institute of Technology, in engineering; J. P. Keane, University of Wales and University of London, to the University of Michigan, in economics ; Edward Lee, University of Manchester, and University of Cambridge, to the University of Michigan, in physics ; Nicholas Miller, Imperial College of Science and Technology, University of London, to the University of California, in engineering; D. G. Northcott, St. John's College, Cambridge, to Princeton University, in mathematics; G. W. Parnell, University of Bristol, to the University of California, in zoology ; J. H. Read, University of St. Andrews, and Emmanuel College, Cambridge, to Columbia University and the American Film Center, New York, in cinematography; J. A. Scott, Trinity College, Oxford, to the University of Pennsylvania, in economics; Dr. E. V. Watson, University of Edinburgh, to Harvard University, in botany ; E. R. Winton, University of St. Andrews, to the Massachusetts Institute of Technology, in engineering; N. A. Wylie, Oriel College, Oxford, to Yale University, in forestry.

THE following have been appointed to fellowships tenable by candidates from the British Dominions : H. C. Corben, University of Melbourne, and Trinity College, Cambridge, to the University of California, in physics; Dr. A. P. Guinand, University of Adelaide, New College, Oxford, to Princeton University, in mathematics. The following have been appointed to fellowships tenable by candidates holding appointments in Government service overseas : H. L. Hume, University of New Zealand, of the Public Works Department, Government of New Zealand, to the University of California, in engineering ; M. R. Jacobs, University of Adelaide, and St. Catherine's Society, Oxford, of the Department of the Interior, Government of Australia, to Yale University, in forestry ; C. S. Kelly, Balliol College, Oxford, of the Indian Civil Service, Government of Burma, to Yale University, in anthropology ; S. L. Macindoe, University of Sydney, of the Department of Agriculture, Government of New South Wales, to the University of Minnesota, in agriculture. The following have been appointed to fellowships tenable 